\title{
VOLCANIC HAZARD ASSESSMENT AT SANTORINI VOLCANO: A REVIEW AND A SYNTHESIS IN THE LIGHT OF THE 2011-2012 SANTORINI UNREST
}

\author{
Vougioukalakis G. ${ }^{1}$, Sparks R.S.J. ${ }^{2}$, Pyle D. ${ }^{3}$, Druitt T. ${ }^{4}$, Barberi F. 5 , \\ Papazachos C. ${ }^{6}$ and Fytikas M. ${ }^{6}$ \\ ${ }^{1}$ Institute of Geology and Mineral Exploration, 13677, Athens, gvoug@igme.gr \\ ${ }^{2}$ Bristol University, School of Earth Sciences, UK, steve.sparks@bristol.ac.uk \\ ${ }^{3}$ Oxford University, Dept. of Earth Sciences, UK, david.pyle@earth.ox.ac.uk \\ ${ }^{4}$ Université Blaise Pascal de Clermont-Ferrand, Laboratoire Magmas et Volcans, France, \\ T.Druitt@opgc.univ-bpclermont.fr \\ ${ }^{5}$ Universita Roma Tre, Italy, franco.barberi@uniroma3.it \\ ${ }^{6}$ Aristotle University of Thessaloniki, Geophysical Laboratory, 54124, Thessaloniki, Greece, \\ kpapaza@geo.auth.gr,fytikas@geo.auth.gr
}

\begin{abstract}
In 2011 and the first half of 2012 Santorini experienced its first seismo-volcanic unrest since 1950, as detected by the permanently installed monitoring networks and a large number of campaign measurements. The unrest was characterized by small magnitude but intense seismic activity, significant uplift and inflation deformation rates, and changes of water temperature as well as offluid and soil gases. While the unrest ended in the spring of 2012, the world-wide interest led to the performance of several studies, in an attempt to assess the possible scenarios for the unrest evolution. Within this framework, we summarize the most important findings regarding the volcanic hazard assessment of the broader Santorini volcanic complex, as well as the constraints that need to be taken into account for a possible future volcanic crisis management.

Keywords: Santorini, volcanic hazard, seismo-volcanic unrest.
\end{abstract}

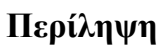

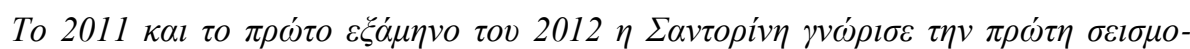

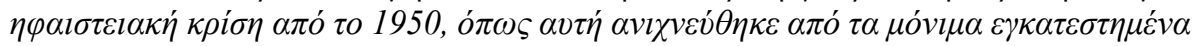

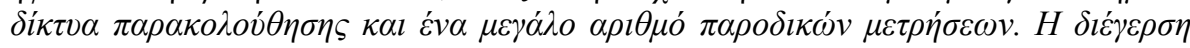

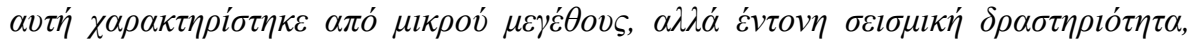

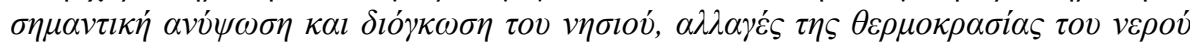

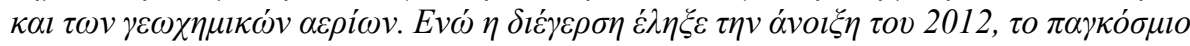

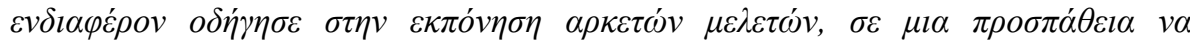

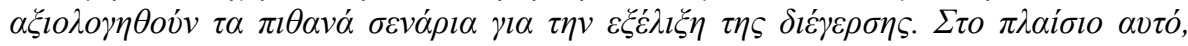

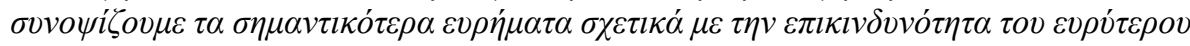

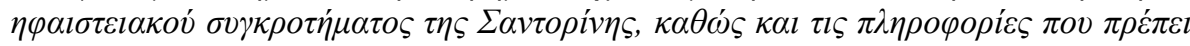

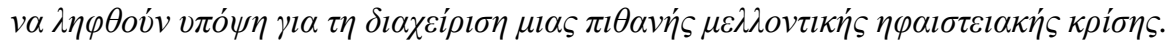

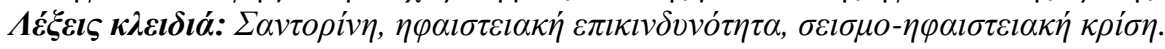




\section{Introduction}

Between 20 January 2011 and March 2012, the Volcano of Santorini (Fig. 1) experienced a state of unrest, the first such period detected since the last eruptive activity in 1950 (Fig. 2). The ISMOSAV monitoring network recorded changes in the monitored parameters (seismicity, topographic changes, thermal state, chemistry of the hot fluids and soil gases; Tassi et al., 2013), and campaign measurements also detected changes in soil gas fluxes and compositions (Parks et al., 2013; Rizzo et al., 2015). In addition, GPS networks (Newman et al., 2012) and satellite radar observations detected ground uplift at rates approaching $1 \mathrm{~cm} / \mathrm{month}$ on parts of the Kameni islands (Parks et al., 2012, 2015; Foumelis et al., 2013; Lagios et al., 2013), with higher (but unmeasured) uplift rates possibly occurring under water.

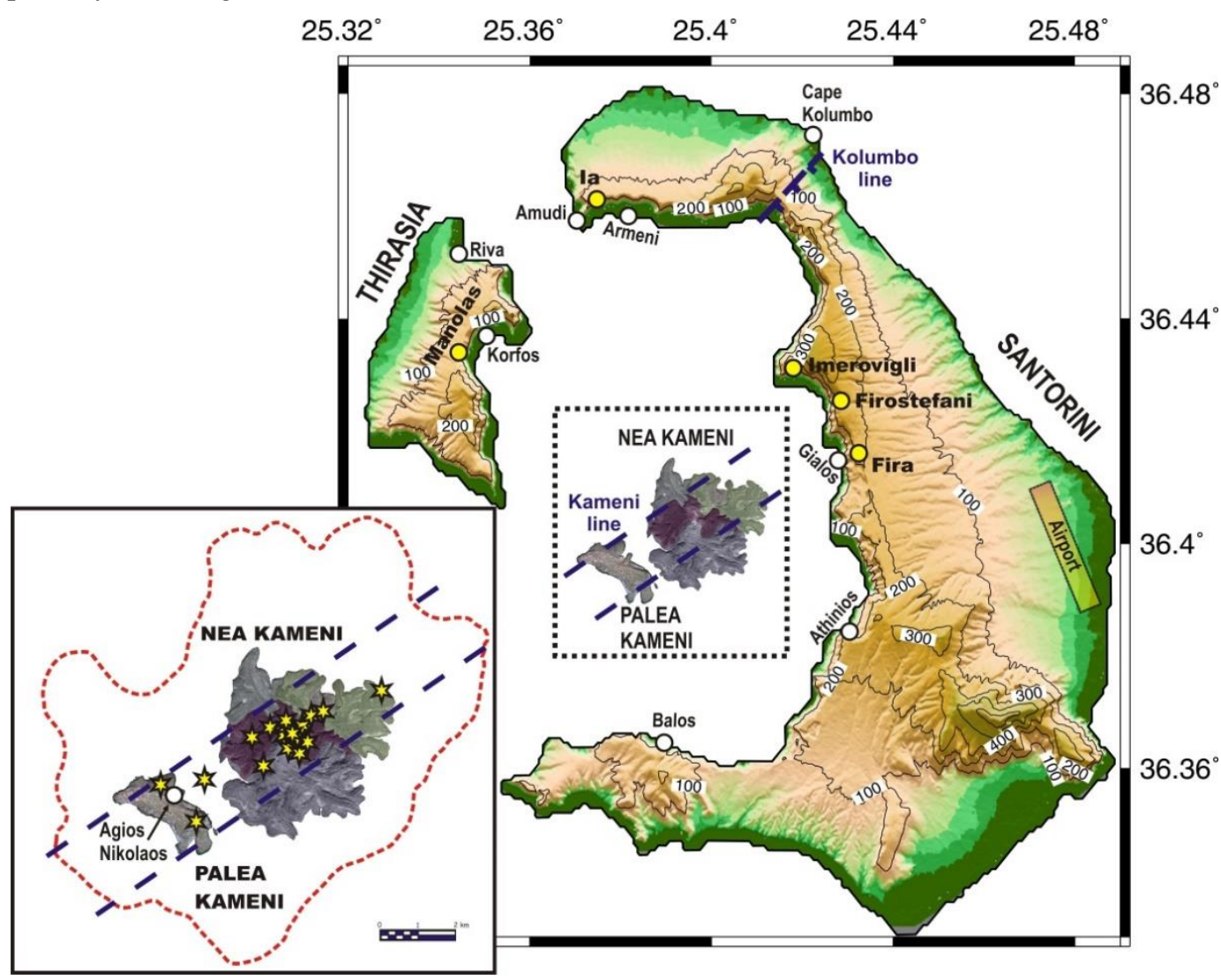

Figure 1 - Schematic morphotectonic map of the Santorini island system. The two main volcano-tectonic lines (Kameni and Kolumbo) are presented with blue dashed lines. The main urban centres and intra-caldera bays/ports are also depicted with yellow and white circles, respectively. The volcanic centers where historical activity initiated, within the Kameni line, are also shown in the inset figure (yellow stars) Red dashed line delimit the submarine Kamenis edifice boundary.

All of these changes exceeded the limits defining the background state of the Kamenis volcanic center, based on the monitoring network data for the last 20 years. Prior to 2011 background seismicity within the Santorini caldera had been very low and deformation was minor (Dimitriadis et al., 2005; Saltogianni and Stiros, 2012). Based on these marked changes starting January 2011, the Kameni islands volcanic center was assessed to be in the initial stage of the advisory phase (yellow color), as defined from the International Alert-Notification Systems for Volcanic Activity (Fearnley et al., 2012; Winson et al., 2014). It was also concluded by the National Scientific 
Committee for the Monitoring of Santorini Volcano (NSCMVC) that: “...It is possible that the volcano will return back to its normal state after an unknown time period without an eruption occurring. It is also possible that the existing volcanic unrest will evolve into a reactivation of the Kamenis volcanic center...". However, by spring 2012, all monitoring networks indicated that the volcano had returned to the previous background state of activity, an observation that was confirmed by geodetic measurements (Saltogianni et al., 2014; Parks et al., 2015).

In the present work we review and summarize the most important issues related to the volcanic hazard assessment for the Santorini volcanic complex, as they have been adapted on the basis of the findings of the 2011-2012 unrest.

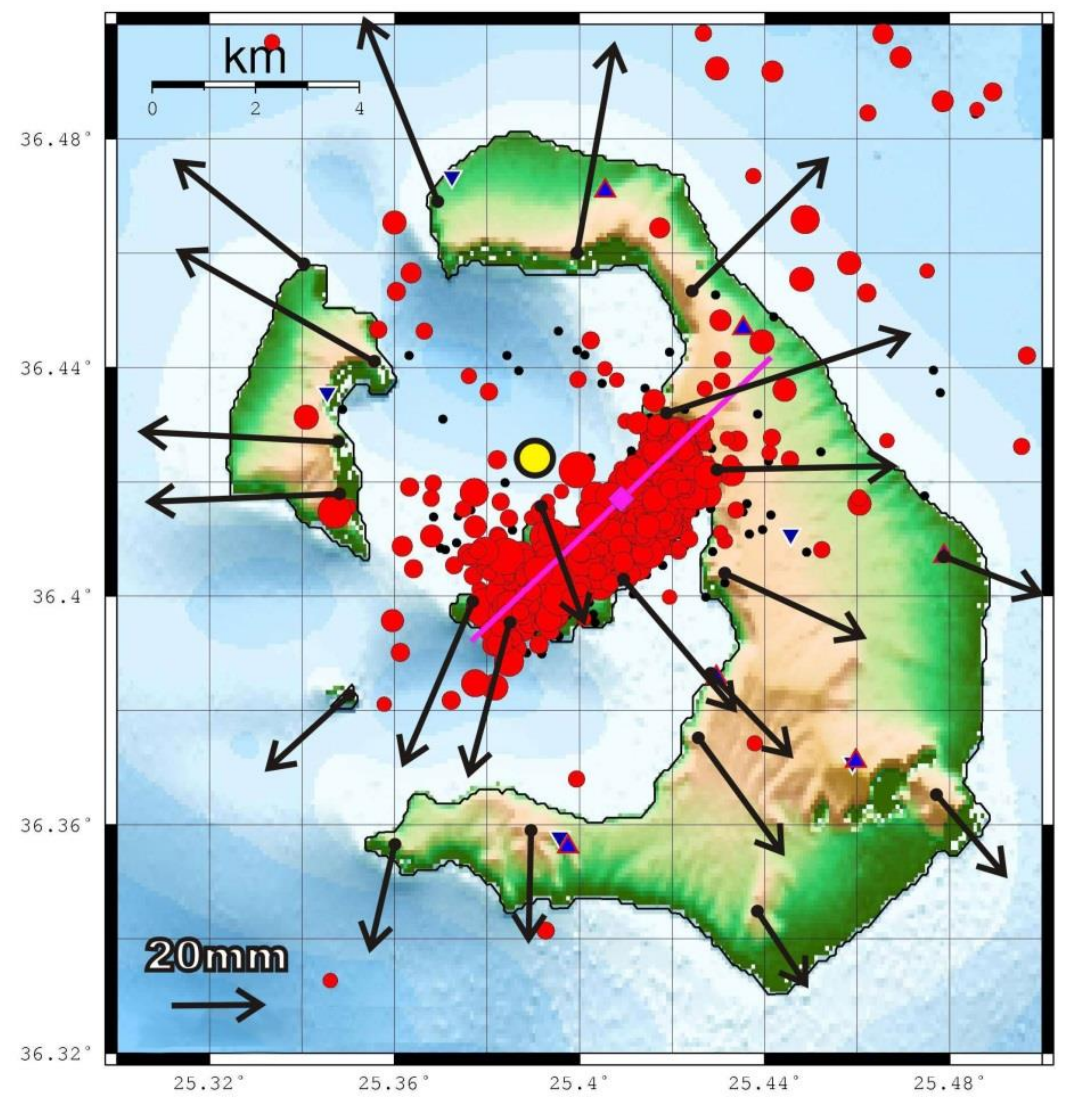

Figure 2 - GPS displacements from 22 sites between 2010 and late August 2011 and the corresponding earthquakes $\left(M_{L}>1.0\right)$ along the Kameni line during the first-phase of the

2011-2012 unrest (data from Newman et al., 2012 and Papazachos et al., 2012a). The proposed position of the Mogi source at the depth of $\sim 4 \mathrm{~km}$ is also shown with a yellow circle.

\section{The 2011-2012 unrest period}

The number of small-magnitude $(M \leq 3.6)$ volcanotectonic earthquakes greatly increased during the 15 -month-long unrest period at depths of 1-6 km on a near-vertical $6 \mathrm{~km}$-long plane along the Kameni line (Newman et al., 2012). The increased seismicity was accompanied by up to $10 \mathrm{~cm}$ inflation of the islands measured by GPS networks and by radar interferometry, corresponding to a modelled volume increase of about 10-20 million $\mathrm{m}^{3}$ at 3-6 $\mathrm{km}$ beneath the northern caldera basin (Newman et al., 2012; Parks et al., 2012; Papoutsis et al., 2013; Foumelis et al., 2013). Small increases in the fluxes of $\mathrm{H} 2$ and mantle-derived $\mathrm{CO}_{2}$ also occurred during the unrest (Parks et al., 2013; Tassi et al., 2013). By combining measurements of $\delta^{13} \mathrm{C}$ and ${ }^{222} \mathrm{Rn}$, Parks et al., (2013) showed 
that the $\mathrm{CO}_{2}$ liberated during the unrest was a mixture of deep-derived magmatic $\mathrm{CO}_{2}$ and $\mathrm{CO}_{2}$ liberated by thermo-metamorphic breakdown of basement limestones.

The changes in the chemical compositions of fumarolic gases on Nea Kameni were interpreted to reflect temperature increases in hydrothermal fluids, due to increased magmatic gas supply at depth (Tassi et al., 2013; Parks et al., 2013; Rizzo et al., 2015). The volume increase associated with deformation was attributed to intrusion of magma and associated fluids (Newman et al., 2012; Parks et al., 2012). Both volume and gas composition changes may also have been in part tectonic in origin due to stress accumulation on regional faults (Feullet, 2013) caused by flexuring of the caldera block and increasing rock permeability and hence gas emissions (Tassi et al., 2013). Input of new magma has been also proposed on the basis of He isotope ratios (Rizzo et al., 2015). Parks et al. (2015), used a 20-year record of GPS and Insar data to reveal a slow $(\sim 6 \mathrm{~mm} / \mathrm{y})$ subsidence of southern Nea Kameni between 1993 and 2010, followed by unrest-related inflation in 2011-2012. The subsidence was attributed to thermal contraction and ground loading due to the 1866-70 lavas. The 15 months of unrest inflation was modelled as a number of discrete pulses (Saltogianni et al., 2014; Parks et al., 2015). The total inflation volume equivalent to about $15 \%$ of the magma expected to have accumulated in the chamber since 1950 based on the past eruption rate of the Kamenis (Pyle and Elliot, 2006; Watts et al., 2015; Johnston et al., 2015). However, it has to be born in mind that volumes estimated by Mogi models can differ from real volumes of intruded magma due to effects of complex pressure source geometry and magma compressibility. A volume related to a given inflation depends on assumptions of chamber size, pressure and elastic properties of the crust. Further inferences on volume of magma depend strongly on the proportion of exsolved compressible magmatic gas in the magma chamber (Huppert and Woods, 2002). In the extreme case if all the volume change is related to exsolved volatiles it is difficult to make any inferences about magma volume.

It was considered urgent, at the beginning of the crisis, to construct the most probable scenarios of volcano reactivation, based on the past behavior of the volcano and available research results. These scenarios would enable estimation of volcanic, seismic and geotechnical hazards, as well as the assessment of the associated risks. On the basis of these data, Civil Defense Authorities could plan actions to undertake for the safety of Santorini inhabitants and visitors, to achieve the minimum disturbance of social and economic activity in the region in case of volcano reactivation.

\section{Volcanic Hazard Assessment}

For the volcanic hazard assessment four scenarios have been examined:

1. The most catastrophic event that could be manifested in the area, ('Highly improbable eruptive scenario')

2. The highest magnitude volcanic event likely to occur, sometimes called the maximum credible event ('Worst-case eruptive scenario')

3. The volcanic event most likely to occur. ('Most likely eruptive scenario')

4. A return to the repose state ('Non-eruptive scenario').

1. Highly improbable eruptive scenario. The first possible event is a plinian eruption similar to the Minoan eruption of the early 17th century BCE (Sparks and Wilson, 1990; Druitt, 2014). About twelve large plinian eruptions have occurred during the last 360,000 years at Santorini, with a recurrence period of about 30,000 years (Druitt et al., 1999). As the time since the Minoan eruption is only 3,600 years, a similar eruption in the near future is considered to be highly improbable. In addition, the historical eruptions have been quite frequent, suggesting that the deep magmatic system is leaking magma gradually, with no build-up of the very large volumes of magma required for a Minoan style eruption. Recent work on the Minoan eruption (Druitt et al., 2012) suggests that the Minoan eruption was preceded by magma intrusion rates that were much higher $\left(\sim 0.05 \mathrm{~km}^{3} / \mathrm{y}\right.$ for about a decade) than occurring at the present time (about $0.01 \mathrm{~km}^{3} / \mathrm{y}$ for only 15 months, based on observed inflation during the unrest period). 
2. Worst-case eruptive scenario. The most intense volcanic event likely to occur today is a sub-plinian explosive eruption. Such an eruption would be expected to develop a plume height of about 8-12 km and to have duration of about 30 minutes. It could deposit a tephra layer with sufficient thickness up to $10 \mathrm{~km}$ downwind to cause roof collapse. Pyroclastic density currents might occur, and these would be extremely dangerous for caldera areas close to the Kameni islands. Sub-plinian eruptions are common at many active volcanoes. For example the Kolumbo 29-30/9/1650 explosive eruption has been estimated to have exhibited a similar intensity. The geological record of Santorini also suggests that eruptions of this scale have occurred approximately once every few thousand years (Druitt et al., 1999). Deposits from sub-plinian eruptions are common in the sequences of tephra accumulated between the major eruptions at Santorini, making it likely that the Kameni Volcano may produce such events in the future (although not necessarily in the near future). However, the recent historic eruptions of the Kameni islands have not manifested eruptions of this kind. The largest explosive event of Kameni in historic times is that of $\mathrm{AD} 726$, which occurred at a vent near the Agios Nikolaos bay of Palea Kameni (Fytikas et al., 1990; Vougioukalakis 1994; Vougioukalakis and Fytikas 2005). This eruption deposited a pumice layer $40-60 \mathrm{~cm}$ thick on Palea Kameni, but only very near to the vent. No historical reports are known concerning effects on the people of Santorini, and no deposits from this eruption have been observed on the main islands of the archipelago. Not enough is known about the AD 726 eruption is establish that it was sub-Plinian in intensity.

There is no evidence for a sub-plinian eruption occurring in the caldera since the Minoan eruption (1614 $\mathrm{BC} \pm 25$ years). However, the presence of sub-plinian tephra inter-stratified between deposits of the older plinian events, leads to the conclusion that a sub-plinian event has to be taken into consideration as a worst-case scenario for Civil Defense planning. The National Scientific Committee for the Monitoring of Santorini Volcano (NSCMVC) has adopted a similar scenario of a sub-plinian event for these purposes.

3. Most likely eruptive scenario. The volcanic event most likely to occur is an intracaldera volcanic eruption of the Kameni centers similar to the historical eruptions (Fytikas et al., 1990; Vougioukalakis, 1994; Vougioukalakis and Fytikas, 2005; Pyle and Elliott, 2006; Jenkins et al., 2015). The vents of all the historical submarine and subaerial eruptions are distributed along a NE-SW-trending zone, $2 \mathrm{~km}$ wide and $12 \mathrm{~km}$ long, known as the Kameni line. Future active volcanic vents are expected along this line. All historic volcanic events had precursory phenomena, like seismic events of 4-6 Mercalli intensity, slow subsidence of the vent area, intense thermal manifestations and chemical changes in the hot fluid composition and volume. When the vent was located in shallow sea floor or on the land, hydrothermal explosions also occurred. The time interval between these precursors and the beginning of magma extrusion varied from a few weeks to a few months.

Initial stages of a future eruption might evolve either slowly or rapidly. During the 1707-11 and 1866-70 eruptions a first, slow ascent and extrusion of degassed magma occurred without any explosive activity for several weeks. During the 1925-26 and 1939-41 eruptions, explosive activity occurred during the first weeks of the eruption. Lava extruded at temperatures of $850-950^{\circ} \mathrm{C}$. The feeding rate was estimated to be $0.5-3 \mathrm{~m}^{3} / \mathrm{s}$, and the height of the growing lava dome was $30-70 \mathrm{~m}$ by the first week, $50-90 \mathrm{~m}$ by the first month, and $90-120 \mathrm{~m}$ in the final phase (Pyle and Elliott, 2006). Explosive activity at Kameni varies between weak vulcanian and Sakurajima type (nearcontinuous weak explosions and ash venting). Typical explosions have durations of 40-60 s, plume heights of $500-1000 \mathrm{~m}$, and ballistic projectile ranges of $1 \mathrm{~km}$. The largest explosions can last 2-3 min, with plumes reaching $3200 \mathrm{~m}$ in height and ballistic projectiles reaching $2 \mathrm{~km}$. There is also rhythmic explosive activity, with more than 60 events per minute, feeding continuously a plume that deposits ash across the Santorini islands. $\mathrm{SO}_{2}$ is the dominant noxious volcanic gas during the first period of an eruption. In the later stages $\mathrm{H}_{2} \mathrm{~S}$ prevails (Dakoronias, 1879). Effusive activity feeds lava flows from lava dome flank fissures, with lengths of $500-1000 \mathrm{~m}$, advancing at about $3 \mathrm{~m} / \mathrm{h}$ in the first stages and slowing down to $0.3 \mathrm{~m} / \mathrm{h}$ in the late stages. 
Active vents during each eruptive period are usually from 2 to 5, and are located along the Kameni line. They can be activated one after the other or contemporaneously. Their inter-distance varies from a few tens to a few hundred meters. Usually the active vents migrate to the NE-SW or N-S during the eruption. The time period during which volcanic centers remain active varies from a few weeks to a few years, with the total eruption lasting from 1 to 5 years. Based on the statistical analysis of the repose time periods, and the total duration of each historic eruption, a reactivation of Kameni centers could lead to an eruption that might last 2 to 3 years (Pyle and Elliot, 2006).

The time-averaged magma eruption rate is estimated at about $1.3 \times 10^{6} \mathrm{~m}^{3}$ per year, taking into account the total time of edifice construction (3600 years) and the volume of the edifice ( $4.3 \pm 0.7$ km3) (Johnston et al., 2015). We cannot estimate with precision if this eruption rate has been constant over the whole period of historic activity or has varied. The most accurate estimation of the magma volume produced is in the 1925-28 eruption, $100 \times 10^{6} \mathrm{~m}^{3}$. With a repose time of 55 years between 1870-1925, the magma production rate agrees approximately with the general estimate. If this is valid, we expect a present reactivation to produce 105 to $122 \times 10^{6} \mathrm{~m}^{3}$. If the present Mogi source models $\left(14-20 \times 10^{6} \mathrm{~m}^{3}\right)$ are caused by magma volume intrusion this volume corresponds to around $15 \%$ of the total volume to be erupted. However, compressibility effects can lead to major differences between 'Mogi source' volumes and intruded volumes (e.g. Rivalta and Segall, 2008; Huppert and Woods, 2002). Thus the apparently small volume change compared to the expected volume of accumulated magma associated with 61 years or repose cannot be used to infer that 20112012 Santorini unrest is benign.

4. Non-eruptive scenario. Another likely outcome of unrest at the Kameni centre is a simple return to the repose state, without any eruptive activity, as it has occurred during 2011-12.

\section{Reactivation scenarios - Plan proposals for NSCMVC}

In the case of a reactivation of the Kameni centres, an eruption similar to the 1925-28 is most likely. We describe the phenomena we expect to occur, and we list some possible actions to be undertaken by the NSCMVC. Some aspects of the rapid hazard and risk assessment for a future eruption are described in Jenkins et al. (2015) in which a scenario-based probabilistic assessment of ash and gas hazard is used to provide information to inform emergency planning.

Precursory phase. A phase of precursory geophysical and geochemical signals is expected at least several days before the volcanic activity onset. The most reliable increased likelihood indications of eruption, based on precursors of historical eruptions, are (Sparks, 2003; Phillipson et al., 2013):

- Onset and increase of harmonic tremor

- $\quad$ Exponentially increasing seismic energy release

- Shallowing of hypocentres of seismicity and/or deformation pressure sources.

- $\quad$ Increase in the rate of ground uplift

- $\quad$ Subsidence around future vent sites

- Increases in fumarole and hot spring discharges

- Increases in $\mathrm{H}_{2} \mathrm{~S} / \mathrm{SO} 2$ and/or $\mathrm{CO}_{2} / \mathrm{H}$ output

- Discolouring of water around future vent sites.

The locations of precursors, and the measurements of the monitoring networks, will result in a first estimate of the location of any future active vents. The most likely location is on Nea Kameni, or in the shallow sea between Nea and Palea Kameni.

During this phase, Civil Defence authorities may need to limit access to Nea and Palea Kameni, as well as to the surrounding sea, which might be subjected to hydrothermal explosions, violent steam releases, and/or ballistic projectiles from an eruption opening phase, as well as subsequent Vulcanian explosions. A Scientific Synthesis Group (SSG) of NSCMVC members, along with an international group of scientists, should be assembled on Santorini, in order to advise, support and help the local and Civil Defence authorities. There is also high probability of shallow seismic events; hence a 
seismic hazard and risk assessment needs to be addressed. Preliminary analysis shows that intracaldera events could damage buildings and infrastructures, mostly in the Fira - Firostefani Imerovigli area and along the caldera rim and cliffs due to topographic amplification phenomena (Papazachos et al., 2012b). It is also important to have an estimate of the geotechnical problems that might occur along the steep caldera cliffs. Landslides and detachments of large masses could trigger small tsunamis, which could threaten the intra-caldera coastline (Korfos, Riva, Amudi, Armeni, Gialos, Balos), as well as the port of Athinios (Fig.2).

Eruptive phase. The first most likely eruptive event is the extrusion of degassed magma, the incipient construction of a lava dome and possibly accompanied by some weak to moderate intensity explosions. If the eruption then evolves rapidly, as it did in 1925, explosive activity could begin a few days, or even a few hours, after the appearance of lava. The SSG will need to use monitoring data to follow the evolution of the eruption, and propose a time when access to the Kameni islands should be prohibited. The area of limited or no access should be extended to the maximum expected ballistic projectiles distance $(2000 \mathrm{~m})$. The scientists will also need to monitor and predict the dispersal of volcanic ash and emissions of volcanic gas, building on the preliminary assessments in Jenkins et al. (2015). The scientists should be based at the volcano observatory. The observatory itself should be situated in northern Thira (region of Ia), which is upwind of the volcano (Jenkins et al., 2015), where appropriate communication facilities and power supplies exist, and where a direct view of the Kameni volcano is afforded. A power generator should be available in case of power supply problems. The site that best fits these requirements is the Ia desalination plan. The SSG should be continuously present on the island during the crisis period. As an eruption may last about 2-4 years, measures and funding to guarantee the availability and presence of specialized scientists should be undertaken. Equipment to measure and monitor volcanic plumes for gas and ash should be available and operative.

The main problems related to ash and gas dispersal will include:

- The management of navigation in the caldera: The present position of the cruise boat anchorage will probably be in the area of prohibited access (explosion and ballistic risk area). Athinios port will be susceptible to ash fallout, gas pollution and geotechnical problems (rock falls, rock mass detachments, landslides and small tsunamis). It will become urgent to find an alternative port location. It should be noticed that the planning of 2 evacuation ports is currently realized, following the 2012-2012 unrest.

- The airport might have to close at times due to ash on the ground and in flight path of aircraft. Measures to maintain the airport as open as possible will have to be taken including ash removal and forecasts of meteorological conditions, which affect the occurrence of ash in the atmosphere along flight paths.

- $\quad$ Power generation and supply, telecommunication problems. The most prominent impact of power outage is the indirect effects on water supply due to pump and desalination plant failure.

- Health effects and environmental impacts (destruction of vine cultivation, contamination of rain water cisterns etc.) due to ash fallout, $\mathrm{SO}^{2}$ pollution and acid rain. We note that $\mathrm{SO}^{2}$ and respirable ash concentrations may exceed World Health Organisation thresholds in periods which might last hours to days according to the analysis of Jenkins et al. (2015).

Civil defence authorities will need to develop operational plans to face all of these emergencies and actions, and to inform the population effectively. Intense interest from the media and the public can be addressed by having a dedicated communications staff in the observatory.

Eruption under the sea. In the case that the active vents are located under the sea, in the area between Palea and Nea Kameni, or between Nea Kameni and Gialos, the absence of direct observation will make monitoring more difficult. The expected turbidity of the water, and the danger of violent steam release, will impair attempts to monitor bathymetric changes by Oceanographic vessels and ROVs. The broader area around the vents should be of prohibited access for boats and ships due to the risk from submarine explosions and gas releases. Explosions underwater could 
generate tsunami waves that could inundate settlements and ports at the base of the caldera cliffs. If the vents are located at depths high enough for water pressure to suppress explosive gas release, then the risk is low. If the composition of the magma feeding the new activity remains the same as in past historic activity (dacite), then also the hazard from water - magma interaction is estimated to be relatively low.

Another minor hazard is the "haze", acidic fumes generated by hot lava - sea water interaction. During historic intra-caldera activity, no problems related to this have been described. On the other hand, the presence of submarine historic centers between Nea Kameni and Gialos, with their summits as shallow as $40 \mathrm{~m}$ below sea level, raises the possibility of a submarine eruption in this area. In this case the area of Fira and the nearby caldera rim are at high risk. It is urgent to carry out a risk assessment for this scenario.

Worse-case scenario. A risk assessment study and reliable scenarios are also urgently needed for a sub-plinian eruption, building on the preliminary study of Jenkins et al. (2015). In this case a partial evacuation plan may be needed.

\section{Recommendations - Conclusions}

The present repose period offers the opportunity for the scientific community, civil defence authority and local authorities to plan for a future eruption. Such plans should include:

1. Comprehensive eruption-related hazard evaluations, including the modelling of different eruptive scenarios and their effects (ash production and dispersal, ballistic projection, etc.), modelling of tsunami generation, etc.

2. Assessments of vulnerability and risk related to the range of unrest-related and eruptionrelated phenomena, such as:

a. The impact of seismic shaking on buildings and cliff stability; an estimation of the geotechnical problems resulting from the large number of constructions on the steep upper parts of the caldera cliffs would be particularly important.

b. The impact of ash plumes on air traffic and airport.

c. Health effects and environmental impacts (destruction of vine cultivation, contamination of rain water cisterns etc.) due to ash fallout and acid rains.

d. The impact of marine exclusion zones on marine traffic.

e. Power generation and supply, telecommunication problems.

f. Impacts specific to the Athinios (main port) and Fira (main town) areas.

3. Risk mitigation procedures, including people movement and (in the worst case scenario) partial evacuation of the islands from a port not threatened by an eruption (the case of Athinios).

4. Simulations of the economic impact of an eruption on the island.

5. Identification of a Scientific Synthesis Group (SSG) of NSCMVC members, and an international group of scientists, to be assembled on Santorini in order to advise, support and help the Civil Defence authorities in the event of crisis.

6. Construction of a new volcano observatory. The observatory should be situated in northern Thira (region of Ia) due to its favourable position in respect to the dominant wind direction and expected ground motions from the Kameni line seismicity, near the caldera rim, having a direct view to the Kameni centres, with appropriate provisions for communication and uninterrupted power supply (e.g. Ia desalination plant).

7. Putting into place public communication protocols.

8. Implementing a public awareness education programme on Santorini. Public and mass media communication is crucial in any volcanic crisis, but is more crucial on Santorini, taking into account the role of the island in the tourist industry of the country. Communication should be done uniquely through the Santorini Committee for Monitoring Unrest. An information board and 
structure, that guarantee rapid and clear information, which will be trusted by people and media, is indispensable. A programme of public education through talks, school visits, radio, internet, film products and television would be essential for informing people of volcanic phenomena and of the evolving situation.

\section{References}

Dakoronias, 1879. De l'influence des emanations volcaniques sur les etres organizes, particulierment etudiée a Santorin pendant l'eruption de 1866, Adrien Delahaye, Paris.

Dimitriadis, I.M., Panagiotopoulos, D.G., Papazachos, C.B., Hatzidimitriou, P.M., Karagianni, E.E. and Kane, I., 2005. Recent seismic activity (1994-2002) of the Santorini volcano using data from local seismological network, Developments in Volcanology: The South Aegean Volcanic Arc, 391 pp. Elsevier, 185-204.

Druitt, T.H., 2014. New insights into the initiation and venting of the Bronze-Age eruption of Santorini (Greece), from component analysis, Bulletin of Volcanology, 76(2), 1-21.

Druitt, T.H., Costa, F., Deloule, E., Dungan, M. and Scaillet, B., 2012. Decadal to monthly timescales of magma transfer and reservoir growth at a caldera volcano, Nature, 482, 77-80.

Druitt, T.H., Edwards, L., Mellors, R.M., Pyle, D.M., Sparks, R.S.J., Lanphere, M., Davies, M. and Barreiro, B., 1999. Santorini Volcano Geological Society of London, Memoir, 19, 178 pp.

Fearnley, C.J., McGuire, W.J., Davis, G. and Twiggs, J., 2012. Standarisation of the USGS Volcano Alert Level System (VALS): analysis and ramifications, Bull. Volcanol, doi: 10.1007/s00445-012-0645-6.

Feuillet, N., 2013. The 2011-2012 unrest at Santorini rift: stress interaction between active faulting and volcanism, Geophysical Research Letters, 40(14), 3532-3537.

Foumelis, M., Trasatti, E., Papageorgiou, E., Stramondo, S. and Parcharidis, I., 2013. Monitoring Santorini volcano (Greece) breathing from space, Geophysical Journal International, 193, 161170.

Fytikas, M., Kolios, N. and Vougioukalakis, G., 1990. Post-Minoan activity of the Santorini volcano: Volcanic hazard and risk, forecasting possibilities. In: Hardy, D.A., Keller, J., Galanopoulos, V.P., Flemming, N.C. and Druitt, T.H., eds., Thera and the Aegean world III, vol. 2., The Thera Foundation, London, 183-198.

Huppert, H.E., and Woods, A.W., 2002. The role of volatiles in magma chamber dynamics, Nature, 420(6915), 493-495.

Jenkins, S.F., Barsotti, S., Hincks, T.K., Neri, A., Phillips, J.C., Sparks, R.S.J., Sheldrake, T. and Vougioukalakis, G., 2015. Rapid emergency assessment of ash and gas hazard for future eruptions at Santorini Volcano, Greece, Journal of Applied Volcanology, 4, 16.

Johnston, E.N., Sparks, R.S.J., Nomikou, P., Livanos, I., Carey, S., Phillips, J.C. and Sigurdsson, H., 2015. Stratigraphic relations of Santorini's intracaldera fill and implications for the rate of post-caldera volcanism, Journal of the Geological Society, 172, 323-335.

Lagios, E., Sakkas, V., Novali, F., Bellotti, F., Ferretti, A., Vlachou, K. and Dietrich, V., 2013. SqueeSAR (TM) and GPS ground deformation monitoring of Santorini Volcano (19922012): Tectonic implications, Tectonophysics, 594, 38-59.

Newman, A.V., Stiros, S., Feng, L., Psimoulis, P., Moschas, F., Saltogianni, V., Jiang, Y., Papazachos, C., Panagiotopoulos, D.G., Karagianni, E. and Vamvakaris, D., 2012. Recent geodetic unrest at Santorini Caldera, Greece, Geophys. Res. Lett., 39, L06309, doi: 10.1029/2012GL051286.

Papazachos, C., Skarlatoudis, A. and Vougioukalakis, G., 2012a. A preliminary deterministic seismic hazard assessment in the Santorini island for the 2011- 2012 volcanic unrest, VOLSAM 2012, Santorini, 10-12 October.

Papazachos, C., Panagiotopoulos, D., Karagianni, E., Vamvakaris, D., Albanakis, K., Laopoulos, Th., Fytikas, M. and Vougioukalakis, G., 2012b. The evolution of the 2011-2012 Santorini volcanic unrest as revealed by seismicity, VOLSAM 2012, Santorini, 10-12 October. 
Papoutsis, I., Papanikolaou, X., Floyd, M., Ji, K.H., Kontoes, C., Paradissis, D. and Zacharis, V., 2013. Mapping inflation at Santorini volcano, Greece, using GPS and InSAR, Geophysical Research Letters, 40(2), 267-272.

Parks, M.M., Biggs, J., England, P., Mather, T.A., Nomikou, P., Palamartchouk, K., Papanikolaou, X., Paradissis, D., Parsons, B., Pyle, D.M., Raptakis, C. and Zacharis, V., 2012. Evolution of Santorini volcano dominated by episodic and rapid fluxes of melt from depth, Nature Geoscience, 5, 749-754.

Parks, M.M., Caliro, S., Chiodini, G., Pyle, D.M., Mather, T.A., Berlo, K., Edmonds, M., Biggs, J., Nomikou, P. and Raptakis, C., 2013. Distinguishing contributions to diffuse $\mathrm{CO}_{2}$ emissions in volcanic areas from magmatic degassing and thermal decarbonation using soil gas ${ }^{222} \mathrm{Rn}-\delta^{13} \mathrm{C}$ systematics: application to Santorini volcano, Greece, Earth and Planetary Science Letters, 377-378, 180-190.

Parks, M.M., Moore, J., Papanikolaou, X., Biggs, J., Mather, T.A., Pyle, D.M., Raptakis, C., Paradissis, D., Hooper, A., Parsons, B. and Nomikou, P., 2015. From quiescence to unrest 20 years of satellite geodetic measurements at Santorini volcano, Greece, Journal of Geophysical Research (Solid Earth), 120, 1309-1328, doi: 10.1002/2014JB011540.

Phillipson, G., Sobradelo, R. and Gottsmann, J., 2013. Global Volcanic Unrest in the 21st Century: An analysis of the first decade. J. Volcanol. Geothermal Res., 264, 183-196.

Pyle, D.M. and Elliott, J.R., 2006. Quantitative morphology, recent evolution and future activity of the Kameni islands volcano, Santorini, Greece, Geosphere 2, 253-268.

Rivalta, E. and Segall, P., 2008. Magma compressibility and the missing source for some dike intrusions, Geophys. Res. Lett., 35, L04306.

Rizzo, A.L., Barberi, F., Carapezza, M.L., Di Piazza, A., Francalanci, L., Sortino, F. and D'Alessandro, W., 2015. New mafic magma refilling a quiescent volcano: Evidence from He-Ne-Ar isotopes during the 2011-2012 unrest at Santorini, Greece, Geochemistry, Geophysics, Geosystems, 16, 798-814, doi: 10.1002/2014GC005653.

Saltogianni, V. and Stiros, S.C., 2012. Modeling the Mogi magma source centre of the Santorini (Thera) volcano, Aegean Sea, Greece, 1994-1999, based on a numerical-topological approach, Stud. Geophys. Geod., 56, 1037-1062, doi: 10.1007/s11200-012-0408-z.

Saltogianni, V., Stiros, S.C., Newman, A.V., Flanagan, K. and Moschas, F., 2014. Time-space modeling of the dynamics of Santorini volcano (Greece) during the 2011-2012 unrest, Journal of Geophysical Research, 119, 8517-8537, doi: 10.1002/2014JB011409.

Sparks, R.S.J. and Wilson, C.J.N., 1990. The Minoan deposits: a review of their characteristics and interpretation, Thera and the Aegean world III, 2, 89-99.

Sparks, R.S.J., 2003. Forecasting Volcanic Eruptions, Earth and Planetary Science Letters Frontiers in Earth Science Series, 210, 1-15.

Tassi, F., Vaselli, O., Papazachos, C.B., Giannini, L., Chiodini, G., Vougioukalakis, G.E., Karagianni, E., Vamvakaris, D. and Panagiotopoulos, D., 2013. Geochemical and isotopic changes in the fumarolic and submerged gas discharges during the 2011-2012 unrest at Santorini caldera (Greece), Bull. Volcanol., 75, 711, doi: 10.1007/s00445-013-0711-8.

Vougioukalakis, G., 1994. Volcanic hazard estimation of Santorini, Aegean Sea, Greece. In: Barberi, F., Casale, R. and Fantechi, R., eds., THE MITIGATION OF VOLCANIC HAZARDS. EUR 16804 EN, 471-484.

Vougioukalakis, G.E. and Fytikas, M., 2005. Volcanic hazards in the Aegean area, relative risk evaluation, monitoring and present state of the active volcanic centers. In: Fytikas, M. and Vougioukalakis, G.E., eds., The South Aegean Active Volcanic Arc - Present Knowledge and Future Perspectives, Dev. Volcano., 7, 161-183.

Watts, A.B., Nomikou, P., Moore, J.D.P., Parks, M.M. and Alexandri, M., 2015. Historical bathymetric charts and the evolution of Santorini submarine volcano, Greece, Geochemistry, Geophysics, Geosystems, 16, 847-869, doi: 10.1002/2014GC005679.

Winson, A.E., Costa, F., Newhall, G.N. and Woo, G., 2014. An analysis of the issuance of volcanic alert levels during volcanic crisis, Journal of Applied Volcanology, 3, 14. 